\section{Impact of 10-valent pneumococcal conjugate vaccine on pneumococcal meningitis in children up to two years of age in Brazil}

\author{
Impacto da vacina pneumocócica conjugada \\ 10-valente na meningite pneumocócica em \\ crianças com até dois anos de idade no Brasil
}

\author{
Impacto de la vacuna neumocócica conjugada \\ 10-valente en la meningitis neumocócica en niños \\ de hasta dos años de edad en Brasil
}

Indianara Maria Grando 1,2

Camile de Moraes 2,3

Brendan Flannery 4

Walter Massa Ramalho 3

Marco Aurélio P. Horta 5

Diana Lucia Moura Pinho 1

Gilmara Lima Nascimento ${ }^{3}$

\footnotetext{
1 Faculdade Ceilândia, Universidade de Brasília, Brasília, Brasil.

2 Secretaria de Vigilância em Saúde, Ministério da Saúde, Brasília, Brasil.

3 Universidade de Brasília, Brasília, Brasil.

4 Global Immunizations Division, Centers for Disease Control and Prevention, Atlanta, U.S.A.

5 Escola Nacional de Saúde Pública Sergio Arouca, Fundação Oswaldo Cruz, Rio de Janeiro, Brasil.

Correspondence I. M. Grando SQN 216 Bloco B, apto. 506 Brasília, DF 70875-020, Brasil.

indiamgrando@gmail.com
}

\begin{abstract}
The objective of this study was to analyze the impact of vaccination against Streptococcus pneumoniae on the morbidity and mortality from pneumococcal meningitis in children $\leq 2$ years in Brazil, from 2007 to 2012. This is a descriptive study and ecological analysis using data from the Information System on Notifiable Diseases. Prevaccination (2007-2009) and post-vaccination (2011-2012) periods were defined to compare incidence rates and mortality. A total of 1,311 cases and 430 deaths were reported during the study period. Incidence decreased from 3.70/100,000 in 2007 to 1.84/100,000 in 2012, and mortality decreased from 1.30/100,000 to 0.40/100,000, or 50\% and $69 \%$ respectively, with the greatest impact in the 6-11 month age group. This decrease in Pneumococcal meningitis morbidity and mortality rates two years after introduction of the 10-valent pneumococcal conjugate vaccine suggests its effectiveness.
\end{abstract}

Streptococcus pneumoniae; Meningitis; Vaccines

\section{Resumo}

O objetivo deste trabalho foi analisar o impacto da vacinação contra o Streptococcus pneumoniae na morbidade e mortalidade por meningite pneumocócica em crianças $\leq 2$ anos, no Brasil, entre 2007-2012. Este é um estudo descritivo com análise ecológica, utilizando dados do Sistema de Informação de Agravos de Notificação. Foram definidos os períodos pré-vacinal (2007-2009) e pós-vacinal (2011-2012) para comparar as taxas de incidência e mortalidade. Foram identificados 1.311 casos e 430 óbitos no período do estudo. A taxa de incidência diminuiu de 3,70/100.000 no ano de 2007 para 1,84/100.000 em 2012, e a mortalidade reduziu de 1,30/100.000 para 0,40/100.000, o que significa uma redução de 50\% e 69\%, respectivamente, com maior impacto identificado na faixa etária de 6 a 11 meses. Os resultados indicam uma diminuição nos indicadores de morbidade e mortalidade de meningite pneumocócica, observados dois anos após a introdução da vacina pneumocócica conjugada 10-valente, sugerindo sua efetividade.

Streptococcus pneumoniae; Meningite; Vacinas 


\section{Introduction}

Streptococcus pneumoniae (pneumococcus) is one of the main etiological agents of bacterial pneumonia, septicemia, and meningitis in children worldwide, accounting for approximately 800 thousand deaths year in children younger than 5 years 1,2,3. In Brazil, pneumococcal meningitis is the second leading cause of bacterial meningitis ${ }^{4}$, especially in infants younger than 1 year ${ }^{5}$. According to data from the SINAN database (Information System on Notifiable Diseases), the mean annual incidence rates in 2001 and 2010 in children younger than 5 years and younger than 1 year were 1.09 and 8.62 cases/100,000 inhabitants, and the mean case-fatality rates were $33.6 \%$ and $31.3 \%$, respectively. Bacterial meningitis has been a disease of compulsory notification in Brazil since 1975.

Advances in the immunogenicity and efficacy of anti-pneumococcal vaccines introduced since 1983 have highlighted their importance in the control and prevention of pneumococcal diseases as the leading cause of vaccine-preventable deaths ${ }^{6}$. Global performance against invasive pneumococcal disease were considered satisfactory using the first pneumococcal conjugate vaccine, including seven serotypes (PCV7), demonstrating $80 \%$ efficacy against invasive pneumococcal disease caused by the seven vaccine serotypes worldwide 7. In Australia, Europe, and North America, the impact of PCV7 on invasive pneumococcal disease was a reduction that varied from $17 \%$ in Spain 8 to $80 \%$ in the United States 9 , with a mean decline of $45 \% 10$. Reductions in invasive pneumococcal disease caused by the seven serotypes in all age groups and associated with childhood vaccination varied from $1 \%$ in the Netherlands 11 to $94 \%$ in the United States 12 , with a mean reduction of $65.5 \% 10$.

In Brazil, 10-valent pneumococcal conjugate vaccine (PCV10) was introduced into the childhood vaccination schedule of the National Immunization Program, Ministry of Health (PNI/ MS) in 2010, with the recommendation of three doses, at two, four, and six months of age, with a booster between 12 and 15 months 13 . The approval of PCV10 was initially based on studies of PCV7, as recommended by the World Health Organization (WHO) 14. Even with the declining trend in pneumococcal meningitis in recent years in Brazil 15, the introduction of PCV10 raises further prospects for controlling pneumococcal disease, with Brazil as the forerunner in implementing this vaccine in its Public Health System.

In this scenario, performance analyses of PCV10 are essential for assessing the intervention's impact. The current study's objectives were to describe cases of pneumococcal meningitis in children up to 2 years of age and to compare the incidence and mortality rates in the pre- and post-implementation periods for the PCV10 vaccine in Brazil, thus contributing knowledge to support meningitis surveillance and strengthen the country's public health policies.

\section{Method}

A descriptive study of cases of pneumococcal meningitis was performed, in addition to an ecological analysis of incidence and mortality rates for the disease in the immediate pre- and postimplementation periods for PCV10. Cases of pneumococcal meningitis included in the study were in children 2 years or younger, recorded in the SINAN database and confirmed by a specific laboratory criterion, which included isolation of S. pneumoniae in culture, latex agglutination reaction, or polymerase chain reaction (PCR).

The introduction of PCV10 vaccine varied between the States of Brazil in 2010, so that year was excluded from the statistical analyses. Thus, the pre-vaccination period was defined as the three years prior to introduction of the vaccine (20072009), and the post-vaccination period included the years 2011 and 2012.

Calculation of the incidence and mortality rates from pneumococcal meningitis used population estimates reported by the Brazilian Institute of Geography and Statistics (IBGE http://www.sidra.ibge.gov.br/bda/tabela/listabl. asp?c $=1552 \& z=c d o=7$, accessed on $22 / \mathrm{Jan} / 2014$; http://www.ibge.gov.br/home/estatistica/popu lacao/trabalhoerendimento/pnad2012/micro dados.shtm, accessed on 22/Jan/2014). Stratification of the population of infants under 1 year (reported by IBGE) into two groups (younger and older than six months) used the proportion of infants under six months according to the database of the Information System on Live Births (SINASC) for each year included in the study (http://tabnet.datasus.gov.br/cgi/sinasc/dados/ nov_indice.htm, accessed on 22/Jan/2014).

Cases of pneumococcal meningitis were described by age group, gender, signs and symptoms, confirmation criterion, evolution, and State and geographic region of residence, as recorded on the notification form. Data on vaccine status were not included, since they showed unsatisfactory completeness.

The study was approved by the Ethics Research Committee of the School of Health Sciences, University of Brasília (CEP/FS-UNB, review n. 171/711). 


\section{Results}

The study included 1,311 cases of pneumococcal meningitis in children up to 2 years of age and reported in the SINAN database from 2007 to 2012. Seventy-nine cases $(5 \%)$ were excluded due to lack of specific laboratory confirmation. The 269 cases (16\%) reported in 2010 were also excluded from the analysis since PCV10 was introduced that year.

Of the 1,311 cases of pneumococcal meningitis, $60 \%(\mathrm{n}=785)$ were in boys. The age group younger than one year accounted for the highest proportion of cases, concentrated in infants younger than six months in the post-vaccination period (Table 1).

The signs and symptoms described in all the study years were fever, vomiting, and seizures. As for confirmation, $69 \%(\mathrm{n}=906)$ of the cases were confirmed by culture, $27 \%(n=357)$ by latex agglutination, and $4 \%(n=48)$ by PCR. Culture was the principal confirmation criterion in all the study years, and there was an increase in cases confirmed by latex and PCR in the post-vaccination period (Table 1).

Approximately $30 \%$ of cases evolved to death each year during the study period, but in the second year of the post-vaccination period this proportion decreased to $22 \%$ (Table 1 ).

The highest proportions of cases in the entire study period were in the Southeast and South regions of Brazil, with $59 \%$ and $16 \%$, respectively. The highest incidence rates were also seen in these regions. Meanwhile, the largest reductions in these rates when comparing 2012 to 2007 were in the States of Minas Gerais and Santa Catarina, both with a decrease of $65 \%$ (Table 2).

Table 3 shows that proportionally, the largest share of cases of pneumococcal meningitis occurred in the year 2007 , with $30 \%$ of the cases from the study period, a proportion that remained relatively stable in 2008 and 2009. The two years of the post-vaccination period showed the lowest proportion of cases, with a decrease

Table 1

Characteristics of cases of pneumococcal meningitis in the pre-vaccination period (2007-2009) and post-vaccination period (2011-2012) for PCV10. Brazil, 2007-2012.

\begin{tabular}{|c|c|c|c|c|c|c|c|c|c|c|}
\hline \multirow[t]{2}{*}{ Variables } & \multicolumn{2}{|c|}{2007} & \multicolumn{2}{|c|}{2008} & \multicolumn{2}{|c|}{2009} & \multicolumn{2}{|c|}{2011} & \multicolumn{2}{|c|}{2012} \\
\hline & n & $\%$ & $\mathbf{n}$ & $\%$ & $\mathrm{n}$ & $\%$ & $\mathbf{n}$ & $\%$ & n & $\%$ \\
\hline \multicolumn{11}{|l|}{ Gender } \\
\hline Male & 222 & 61.7 & 200 & 62.7 & 177 & 61.5 & 106 & 55.2 & 80 & 52.6 \\
\hline Female & 138 & 38.3 & 119 & 37.3 & 111 & 38.5 & 86 & 44.8 & 72 & 47.4 \\
\hline \multicolumn{11}{|l|}{ Age group } \\
\hline \multicolumn{11}{|l|}{$<1$ year } \\
\hline$<6$ months & 136 & 37.8 & 98 & 30.7 & 98 & 34.0 & 111 & 57.8 & 78 & 51.3 \\
\hline$\geq 6$ months & 124 & 34.4 & 120 & 37.6 & 109 & 37.8 & 39 & 20.3 & 29 & 19.1 \\
\hline 1 year & 74 & 20.6 & 75 & 23.5 & 53 & 18.4 & 21 & 10.9 & 26 & 17.1 \\
\hline 2 years & 26 & 7.2 & 26 & 8.2 & 28 & 9.7 & 21 & 10.9 & 19 & 12.5 \\
\hline \multicolumn{11}{|l|}{ Signs and symptoms } \\
\hline Fever & 336 & 93.3 & 314 & 98.4 & 266 & 92.4 & 174 & 90.6 & 136 & 89.5 \\
\hline Vomiting & 235 & 65.3 & 227 & 71.2 & 180 & 62.5 & 116 & 60.4 & 89 & 58.6 \\
\hline Seizures & 164 & 45.6 & 154 & 48.3 & 119 & 41.3 & 76 & 39.6 & 61 & 40.1 \\
\hline Neck stiffness & 138 & 38.3 & 137 & 42.9 & 117 & 40.6 & 58 & 30.2 & 52 & 34.2 \\
\hline Bulging fontanelle & 116 & 32.2 & 89 & 27.9 & 82 & 28.5 & 58 & 30.2 & 50 & 32.9 \\
\hline \multicolumn{11}{|l|}{ Confirmatory criterion } \\
\hline Culture & 277 & 76.9 & 222 & 69.6 & 205 & 71.2 & 114 & 59.4 & 88 & 57.9 \\
\hline Latex & 80 & 22.2 & 87 & 27.3 & 73 & 25.3 & 68 & 35.4 & 49 & 32.2 \\
\hline PCR & 3 & 0.8 & 10 & 3.1 & 10 & 3.5 & 10 & 5.2 & 15 & 9.9 \\
\hline \multicolumn{11}{|l|}{ Evolution } \\
\hline Cure & 204 & 56.7 & 175 & 54.9 & 166 & 57.6 & 112 & 58.3 & 97 & 63.8 \\
\hline Death & 127 & 35.3 & 106 & 33.2 & 97 & 33.7 & 65 & 33.9 & 33 & 21.7 \\
\hline
\end{tabular}

Source: Information System on Notifiable Diseases (SINAN). 
Table 2

Distribution of incidence rates (IR) * and mortality rates (MR) ** from pneumococcal meningitis in the Southeast and

South regions and States of Brazil, 2007-2012.

\begin{tabular}{|c|c|c|c|c|c|c|c|c|c|c|}
\hline \multirow[t]{2}{*}{ Region/State } & \multicolumn{2}{|c|}{2007} & \multicolumn{2}{|c|}{2008} & \multicolumn{2}{|c|}{2009} & \multicolumn{2}{|c|}{2011} & \multicolumn{2}{|c|}{2012} \\
\hline & IR & MR & IR & MR & IR & MR & IR & MR & IR & MR \\
\hline Southeast & 5.65 & 2.08 & 4.88 & 1.73 & 4.78 & 1.84 & 3.93 & 1.42 & 2.99 & 0.69 \\
\hline MG & 3.74 & 1.66 & 3.70 & 1.59 & 2.91 & 1.18 & 2.99 & 1.04 & 1.29 & 0.52 \\
\hline ES & 5.53 & 1.66 & 1.72 & 1.15 & 4.06 & 1.16 & 3.37 & 1.35 & 2.67 & 1.34 \\
\hline RJ & 5.86 & 3.15 & 4.83 & 1.96 & 5.44 & 3.68 & 5.81 & 2.66 & 3.62 & 0.82 \\
\hline SP & 6.55 & 1.94 & 5.83 & 1.78 & 5.62 & 1.61 & 3.73 & 1.16 & 3.58 & 0.67 \\
\hline South & 5.00 & 1.52 & 4.93 & 1.16 & 4.55 & 0.93 & 2.33 & 0.65 & 2.59 & 0.37 \\
\hline PR & 5.73 & 2.55 & 5.77 & 1.77 & 4.36 & 0.69 & 2.29 & 0.23 & 3.64 & 0.91 \\
\hline SC & 5.72 & 1.14 & 4.81 & 0.40 & 4.56 & 2.07 & 2.01 & 0.80 & 1.99 & 0.00 \\
\hline RS & 3.80 & 0.67 & 4.09 & 0.96 & 4.76 & 0.50 & 2.58 & 1.03 & 1.80 & 0.00 \\
\hline Brazil & 3.70 & 1.30 & 3.38 & 1.12 & 3.12 & 1.06 & 2.29 & 0.79 & 1.80 & 0.39 \\
\hline
\end{tabular}

ES: Espírito Santo; MG: Minas Gerais; PR: Paraná; RJ: Rio de Janeiro; RS: Rio Grande do Sul; SC: Santa Catarina;

SP: São Paulo.

* Cases $/ 100,000$ inhabitants;

** Deaths $/ 100,000$ inhabitants.

of $14.6 \%$ in 2011 and $11.6 \%$ in 2012 , accounting for a $58 \%$ reduction in the absolute number of cases when comparing 2012 to 2007. The highest incidence and mortality rates were in infants younger than one year throughout the study period (Table 3).

The study showed a $50 \%$ reduction in the incidence rate and $69 \%$ in the mortality rate from pneumococcal meningitis, comparing 2012 to 2007. Children six months to one year of age showed the highest reductions in rates: $73 \%$ in incidence and $85 \%$ in mortality (Table 3 ).

The reductions in rates identified in this study two years after introduction of the PCV10 were associated with vaccination coverage rates of $73 \%$ in 2011 and $89 \%$ in 2012, according to data from the PNI.

\section{Discussion}

After introduction of the 10 -valent pneumococcal conjugate vaccine in Brazil, there was a reduction in the number of cases and in the incidence of pneumococcal meningitis in children younger than 2 years in 2012. There was an important reduction in the incidence rate for pneumococcal meningitis, especially in the second year post-vaccination when compared to the year 2007. The findings are similar to those in North America and Australia, where the incidence of invasive pneumococcal disease, includ- ing meningitis, declined by $56 \%-69 \%$ in children younger than 2 years, following introduction of PCV7 16,17,18,19,20,21,22,23. In Europe, in the same age group, the reduction was $82 \%$ after the introduction of PCV7 24

In Brazil, the highest incidence of pneumococcal meningitis affects children younger than 2 years 15 . The largest decrease in the incidence rate for pneumococcal meningitis was in the 6-11 month group. This corroborates a populationbased study in Brazil in 2012, relating invasive pneumococcal disease to pneumonias 25. Another finding was the reduction in the incidence of pneumococcal meningitis in the second year post-vaccination in infants younger than six months, similar to a study in the United States in 2006, showing a $40 \%$ decrease in IPD in infants from birth to 90 days of age 21,25 .

This study's results suggest the benefit of PCV10 in reducing the incidence of pneumococcal meningitis, since the current literature refers to the impact of PCV7 used in other countries, with differences in the composition compared to PCV10, the latter with the addition of three more serotypes: 1, 5, and 7F. In Finland, results of a randomized clinical trial showed $92 \%$ and $100 \%$ efficacy rates for PCV10 using vaccination schemes of $2+1$ and $3+1$ doses, respectively ${ }^{26}$. In Quebec, PCV7 was replaced by PCV10 five years after the former was introduced, and the data show lower incidence of invasive pneumococcal disease in children vaccinated with PCV10 
Table 3

Characteristics of cases, annual proportions, incidence rates (IR) * and mortality rates, (MR) ** by age bracket for pneumococcal meningitis in the pre-vaccination period (2007-2009) and post-vaccination period (2011-2012) for PCV10. Brazil, 2007-2012.

\begin{tabular}{|c|c|c|c|c|c|c|c|c|c|c|c|c|c|c|c|c|}
\hline \multirow[t]{3}{*}{ Incidence/Age group } & \multicolumn{9}{|c|}{ Pre-vaccination } & \multicolumn{7}{|c|}{ Post-vaccination } \\
\hline & \multicolumn{3}{|c|}{2007} & \multicolumn{3}{|c|}{2008} & \multicolumn{3}{|c|}{2009} & \multicolumn{3}{|c|}{2011} & \multicolumn{3}{|c|}{2012} & \multirow{2}{*}{$\begin{array}{c}\text { Total } \\
\mathbf{n}\end{array}$} \\
\hline & $\mathbf{n}$ & $\%$ & IR & $\mathbf{N}$ & $\%$ & IR & n & $\%$ & IR & $\mathbf{n}$ & $\%$ & IR & $\mathbf{n}$ & $\%$ & IR & \\
\hline \multicolumn{17}{|l|}{$<1$ year } \\
\hline$<6$ months & 136 & 26.1 & 8.92 & 98 & 18.8 & 6.47 & 98 & 18.8 & 6.71 & 111 & 21.3 & 8.46 & 78 & 15.0 & 5.88 & 521 \\
\hline$\geq 6$ months & 124 & 29.5 & 7.46 & 120 & 28.5 & 7.65 & 109 & 25.9 & 7.02 & 39 & 9.3 & 2.74 & 29 & 6.9 & 2.02 & 421 \\
\hline 1 year & 74 & 29.7 & 2.28 & 75 & 30.1 & 2.39 & 53 & 21.3 & 1.73 & 21 & 8.4 & 0.77 & 26 & 10.4 & 0.95 & 249 \\
\hline 2 years & 26 & 21.7 & 0.79 & 26 & 21.7 & 0.81 & 28 & 23.3 & 0.89 & 21 & 17.5 & 0.76 & 19 & 15.8 & 0.68 & 120 \\
\hline Total & 360 & 27.5 & 3.70 & 319 & 24.3 & 3.38 & 288 & 22.0 & 3.12 & 192 & 14.6 & 2.34 & 152 & 11.6 & 1.84 & 1311 \\
\hline \multirow[t]{3}{*}{ Mortality/Age group } & \multicolumn{9}{|c|}{ Pre-vaccination } & \multicolumn{7}{|c|}{ Post-vaccination } \\
\hline & & 2007 & & & 2008 & & & 2009 & & & 2011 & & & 2012 & & Total \\
\hline & $\mathrm{n}$ & $\%$ & MR & $\mathbf{N}$ & $\%$ & MR & $\mathrm{n}$ & $\%$ & MR & $\mathrm{n}$ & $\%$ & MR & n & $\%$ & MR & $n$ \\
\hline \multicolumn{17}{|l|}{$<1$ year } \\
\hline$<6$ months & 40 & 16.5 & 2.62 & 111 & 45.7 & 1.31 & 36 & 14.8 & 2.46 & 39 & 16.0 & 2.97 & 17 & 7.0 & 1.28 & 243 \\
\hline$\geq 6$ months & 54 & 35.1 & 3.25 & 39 & 25.3 & 0.36 & 42 & 27.3 & 2.71 & 12 & 7.8 & 0.84 & 7 & 4.5 & 0.49 & 154 \\
\hline 1 year & 25 & 33.3 & 0.77 & 21 & 28.0 & 0.32 & 14 & 18.7 & 0.46 & 9 & 12.0 & 0.33 & 6 & 8.0 & 0.22 & 75 \\
\hline 2 years & 8 & 18.2 & 0.24 & 21 & 47.7 & 0.94 & 6 & 13.6 & 0.19 & 6 & 13.6 & 0.22 & 3 & 6.8 & 0.11 & 44 \\
\hline Total & 127 & 24.6 & 1.30 & 192 & 37.2 & 1.12 & 98 & 19.0 & 1.06 & 66 & 12.8 & 0.80 & 33 & 6.4 & 0.40 & 516 \\
\hline
\end{tabular}

* Cases/100,000 inhabitants;

** Deaths/100,000 inhabitants.

compared to PCV7 27. Importantly, the surveillance data used in the current study did not identify the pneumococcal serotypes, which would have allowed assessing the vaccine's specific impact on the vaccine serotypes, thus representing a limitation to the study. The vaccine's impact on the incidence of pneumococcal meningitis depends on the prevalence of circulating serotypes in the population, vaccine coverage, and time since the vaccine's introduction. Although this study did not aim to discuss State-by-State differences in incidence and mortality rates for pneumococcal meningitis, it is important to mention that four States of Brazil (Distrito Federal, Ceará, Rio de Janeiro, and São Paulo) implemented vaccination schemes that differed from the guidelines of the PNI in terms of age at application of the doses.

A study in Salvador, Brazil, estimated $77 \%$ coverage for PCV10 in children younger than 2 years 28. In Goiânia, another study suggested $80 \%$ coverage in children 28 days to 36 months of age 29 . The reductions in the rates identified in this study two years after the introduction of PCV10 can be attributed to introduction of the vaccine, corroborating a study in the United
States that reported a $64 \%$ decline in the incidence of pneumococcal meningitis in children younger than 2 years, five years after the introduction of PCV7 23.

According to studies in France, England, and Wales, two years after the introduction of PCV7 and with vaccine coverage of $75 \%$ or higher, there was a $30 \%-65 \%$ reduction in the incidence of invasive pneumococcal disease from all serotypes. Just one year after vaccination, Germany, Norway, and Denmark reported a $45-57 \%$ decline in invasive pneumococcal disease. Thus, the reduction in Europe was systematically lower than in the United States, where the incidence of invasive pneumococcal disease in children younger than 2 years decreased $69 \%$ only one year after introduction of the vaccine 16 and $76 \%$ in children younger than 5 years, seven years after introduction of PCV712. In Calgary, Canada, the results in children younger than 2 years were similar: overall incidence of invasive pneumococcal disease decreased by $69.9 \%$, and the reduction for the PCV7 serotypes was $88.7 \% 17$.

As for mortality, the current study's results show a consistent drop in the number of deaths when comparing pre- and post-introduction of 
PCV10, with a reduction in both the absolute number and mortality rate, especially in the 6-11 month age group, and in the second year postvaccination in children younger than six months, representing a herd effect, as described in previous studies 21 .

The reduction in the number of deaths and in the mortality rate corroborate the findings by Hicks et al. 30 in the United States, reporting a decline in mortality from invasive pneumococcal disease due to vaccine serotypes in children younger than 2 years, and other studies reporting reductions of $62.5 \%$ and $57.1 \%$ in overall mortality from invasive pneumococcal disease in children eligible for vaccination 12,31. A study in Gambia using a 9-valent pneumococcal vaccine (PCV9) showed a $16 \%$ reduction in infant mortality, with similar reductions in disease shown in South Africa 32.

In terms of case-fatality, the current study's findings corroborate those of Berezin et al. 33, with $20 \%$ case-fatality from pneumococcal meningitis, and the results published by Menezes et al. ${ }^{28}$, with a $28.6 \%$ drop in children younger than 15 years and $41.9 \%$ in those younger than 5 years. Despite the observed impact on pneumococcal disease and even with advances in patient care, the case-fatality rates vary between adults 34 and children 35,36 . For meningitis, the observed decrease is $16 \%$ to $37 \%$ in children and $1 \%$ to $3 \%$ in adults 37 , consistent with the estimates of $8 \%$ and $12 \%$ that have not changed in 20 years, despite progress in diagnosis and treatment 38,39 .
Concerning gender, a study in the United States found that the proportion of cases of pneumococcal meningitis was higher in males than in females 40. In Brazil, results of different studies are similar 15,28,41 and consistent with the current study's findings.

The use of secondary data in epidemiological studies can pose limitations, prone to biases, ranging from case capture to data entry. In addition, ecological analyses are not indicated for determining causality, since other changes that occur simultaneously with introduction of the vaccine are not controlled and demonstrated in the study, thus suggesting the need for future work to consolidate the findings. Still, this study's results provide important evidence on the impact of the 10 -valent pneumococcal conjugate vaccine in reducing pneumococcal meningitis in Brazil.

Finally, the current study's results demonstrate that two years after introduction of PCV10 in Brazil there were important decreases in incidence and mortality rates, highlighting the importance of prevention. Active surveillance of pneumococcal disease is necessary, with continuing evaluation of the epidemiological profile and pattern of circulating serotypes.

\section{Resumen}

El objetivo de este estudio fue analizar el impacto de la vacunación contra el Streptococcus pneumoniae en la morbilidad y mortalidad de la meningitis neumocócica en niños $\leq 2$ años en Brasil, 2007-2012. Se trata de un estudio descriptivo ecológico que analiza los datos del Sistema de Información Enfermedades de Notificación Obligatoria en Brasil. El período previo (2007-2009) y posterior a la vacunación (2011-2012) fueron examinados para comparar las tasas de incidencia y mortalidad. 1.311 casos de meningitis neumocócica con 430 muertes se registraron durante el período de estudio. Hubo una disminución de la incidencia de 3,70 ca- sos por 100.000 habitantes en 2007, a 1,84/100.000 en 2012, mientras que la tasa de mortalidad cayó 1,30 a 0,40 óbitos/100.000, se produjeron reducciones del 50\% y 69\%, respectivamente, con mayores impactos identificados entre los niños de 6-11 meses de edad. Los resultados indican una reducción en la morbilidad y mortalidad por meningitis neumocócica dos años después de la introducción de la vacuna conjugada antineumocócica 10-valente, lo que sugiere su eficacia.

Streptococcus pneumoniae; Meningitis; Vacunas 


\section{Contributors}

I. M. Grando, C. Moraes, B. Flannery, W. M. Ramalho, M A. P. Horta, D. L. M. Pinho, and G. L. Nascimento contributed to the project conceptualization and design, data analysis and interpretation, writing of the article, relevant critical revision of the intellectual content, and approval of the final version for publication. They were responsible for all aspects involved in guaranteeing the accuracy and integrity of all parts of the work.

\section{Acknowledgments}

The authors wish to thank the Health Surveillance Secretariat of the Brazilian Ministry of Health for granting access to the database and the Capes agency (Coordination for the Improvement of Higher Education) for the research grant.

\section{References}

1. World Health Organization. Pneumococcal conjugate vaccine for childhood immunization: WHO position paper. Wkly Epidemiol Rec 2007; 82: 93-104.

2. O'Brien KL, Wolfson LJ, Watt JP, Henkle E, DeloriaKnoll M, McCall N, et al. Burden of disease caused by Streptococcus pneumoniae in children younger than 5 years: global estimates. Lancet 2009; 374:893-902.

3. Initiative for Vaccine Research, Department of Immunization, Vaccines and Biologicals. Proceedings of the Sixth Global Vaccine Research Forum and Parallel Satellite Symposia. Geneva: WHO Press; 2006.

4. Andrade ALSS, Pimenta FC, Brandileone MCC, Laval CA, Guerra ML, Andrade JG, et al. Genetic relationship between Streptococcus pneumoniae isolates from nasopharyngeal and cerebrospinal fluid of two infants with pneumococcal meningitis. J Clin Microbiol 2003; 41:3970-2.

5. Berezin EN, Carvalho LH, Lopes CR, Sanajotta AT, Brandileone MC, Menegatti S, et al. Meningite pneumocócica em crianças: achados clínicos, sorotipos mais frequentes e prognóstico. J Pediatr (Rio J.) 2002; 78:19-23.
6. Centers for Diseae Control and Prevention. Vaccine preventable deaths and the Global Immunization Vision and Strategy, 2006-2015. MMWR Morb Mortal Wkly Rep 2006; 55:511-5.

7. Lucero MG, Dulalia VE, Nillos LT, Williams G, Parreno RA, Nohynek H, et al. Pneumococcal conjugate vaccines for preventing vaccine-type invasive pneumococcal disease and X-ray defined pneumonia in children less than two years of age. Cochrane Database Syst Rev 2009; (4):CD004977.

8. Barricarte A, Gil-Setas A, Torroba L, Castilla J, Petit A, Polo I, et al. Enfermedad neumocócica invasiva en la población menor de 5 años de edad de Navarra (2000-2005): impacto de la vacuna conjugada. Med Clin (Barc), 2007; 129:41-5.

9. Atkinson W, Hamborsky J, McIntyre L, Stanton A, Wolfe C. Epidemiology and prevention of vaccinepreventable diseases. 10 $10^{\text {th }}$ Ed. Washington DC: Public Health Foundation; 2008.

10. Myint TTH, Madhava H, Balmer P, Christopoulou D, Attal S, Menegas D, et al. The impact of 7-valent pneumococcal conjugate vaccine on invasive pneumococcal disease: a literature review. Adv Ther 2013; 30:127-51. 
11. Rodenburg GD, de Greeff SC, Jansen AGCS, de Melker HE, Schouls LM, Hak E, et al. Effects of pneumococcal conjugate vaccine 2 years after its introduction, the Netherlands. Emerg Infect Dis 2010; 16:816-23.

12. Pilishvili T, Lexau C, Farley MM, Hadler J, Harrison LH, Bennett NM, et al. Sustained reductions in in vasive pneumococcal disease in the era of conjugate vaccine. J Infect Dis 2010; 201:32-41.

13. Secretaria de Vigilância em Saúde, Ministério da Saúde. Guia de vigilância epidemiológica. $7^{\mathrm{a}} \mathrm{Ed}$. Brasília: Ministério da Saúde; 2010. (Série A. Normas e Manuais Técnicos).

14. World Health Organization. Expert Committee on Biological Standardization. Recommendations to assure the quality, safety and efficacy of pneumococcal conjugate vaccines. Geneva: Wolrd Health Organization; 2009.

15. Azevedo LCP, Toscano CM, Bierrenbach AL. Bacterial meningitis in Brazil: baseline epidemiologic assessment of the decade prior to the introduction of pneumococcal and meningococcal vaccines. PLoS One 2013; 8:e64524.

16. Whitney CG, Farley MM, Hadler J, Harrison LH, Bennett NM, Lynfield R, et al. Decline in invasive pneumococcal disease after the introduction of protein-polysaccharide conjugate vaccine. $\mathrm{N}$ Engl J Med 2003; 348:1737-46.

17. Kellner JD, Church DL, MacDonald J, Tyrrell GJ, Scheifele D. Progress in the prevention of pneumococcal infection. CMAJ 2005; 173:1149-51.

18. Roche P, Krause V, Cook H, Bartlett M, Coleman $\mathrm{D}$, Davis $\mathrm{C}$, et al. Invasive pneumococcal disease in Australia, 2005. Commun Dis Intell Q Rep 2007; 31:86-100.

19. Hsu K, Pelton S, Karumuri S, Heisey-Grove D, Klein J. Population based surveillance for childhood invasive pneumococcal disease in the era of conjugate vaccine. Pediatr Infect Dis J 2005; 24:17-23.

20. Black S, Shinefield H, Baxter R, Austrian R, Bracken L, Hansen J, et al. Postlicensure surveillance for pneumococcal invasive disease after use of heptavalent pneumococcal conjugate vaccine in Northern California Kaiser Permanente. Pediatr Infect Dis J 2004; 23:485-9.

21. Poehling KA, Talbot TR, Griffin MR, Craig AS, Whitney CG, Zell E. Invasive pneumococcal disease among infants before and after introduction of pneumococcal conjugate vaccine. JAMA 2006; 295:1668-74

22. Kaplan SL, Mason Jr. EO, Wald ER, Schutze GE, Bradley JS, Tan TQ, et al. Decrease of invasive pneumococcal infections in children among 8 children's hospitals in the United States after the introduction of the 7-valent pneumococcal conjugate vaccine. Pediatrics, 2004; 113:443-9.

23. Hsu HE, Shutt KA, Moore MR, Beall BW, Bennett NM, Craig AS, et al. Effect of pneumococcal conjugate vaccine on pneumococcal meningitis. $\mathrm{N}$ Engl J Med 2009; 360:244-56.
24. Dubos F, Marechal I, Husson MO, Courouble C, Aurel M, Martinot A. Decline in pneumococcal meningitis after the introduction of the heptavalent-pneumococcal conjugate vaccine in northern France. Arch Dis Child 2007; 92:1009-12.

25. Carter RJF. Infants too young to receive pneumococcal conjugate vaccine benefit from herd immunity. Thorax 2006; 61:610.

26. Palmu AA, Jokinen J, Borys D, Nieminen H, Ruokokoski E, Siira L, et al. Effectiveness of the ten-valent pneumococcal Haemophilus influenzae protein D conjugate vaccine (PHiD-CV10) against invasive pneumococcal disease: a cluster randomised trial. Lancet 2013; 381:214-22.

27. De Wals P, Lefebvre B, Defay F, Deceuninck G, Boulianne N. Invasive pneumococcal diseases in birth cohorts vaccinated with PCV-7 and/or PHiD-CV in the province of Quebec, Canada. Vaccine 2012; 30:6416-20.

28. Menezes APO, Campos LC, Santos MS, Azevedo J, Santos RCN, Carvalho MGS, et. al. Serotype distribution and antimicrobial resistance of Streptococcus pneumoniae prior to introduction of the 10-valent pneumococcal conjugate vaccine in Brazil, 2000-2007. Vaccine 2011; 29:1139-44.

29. Andrade AL, Oliveira R, Vieira MA, Minamisava R, Pessoa Jr. V, Brandileone MCC, et al. Populationbased surveillance for invasive pneumococcal disease and pneumonia in infants and young children in Goiânia, Brazil. Vaccine 2012; 30:1901-9.

30. Hicks LA, Harrison LH, Flannery B, Hadler JL, Schaffner W, Craig AS, et al. Incidence of pneumococcal disease due to nonpneumococcal conjugate vaccine (PCV7) serotypes in the United States during the era of widespread PCV7 vaccination, 1998-2004. J Infect Dis 2007; 196:1346-54.

31. Pulido M, Sorvillo F. Declining invasive pneumococcal disease mortality in the United States, 1990 2005. Vaccine 2010; 28:889-92.

32. Klugman KP, Madhi SA, Huebner RE, Kohberger R, Mbelle N, Pierce N, et al. A trial of a 9-valent pneumococcal conjugate vaccine in children with and those without HIV infection. N Engl J Med 2003; 349:1341-8.

33. Berezin EN, Carvalho LH, Lopes CR, Sanajotta AT, Brandileone MC, Menegatti S, et al. Meningite pneumocócica em crianças: achados clínicos, sorotipos mais frequentes e prognóstico. J Pediatr (Rio J.) 2002; 78:19-23.

34. Weisfelt M, van de Beek D, Spanjaard L, Reitsma JB, de Gans J. Clinical features, complications, and outcome in adults with pneumococcal meningitis: a prospective case series. Lancet Neurol 2006; 5:123-9.

35. Schuchat A, Robinson K, Wenger JD, Harrison LH, Farley M, Reingold AL, et al. Bacterial meningitis in the United States in 1995. N Engl J Med 1997; 337:970-6. 
36. Haddy RI, Perry K, Chacko CE, Helton WBBS, Bowling MG, Looney SW, et al. Comparison of incidence of invasive Streptococcus pneumoniae disease among children before and after introduction of conjugated pneumococcal vaccine. Pediatr Infect Dis J 2005; 24:320-3.

37. Lynch 3rd JP, Zhanel GG. Streptococcus pneumoniae: epidemiology, risk factors, and strategies for prevention. Semin Respir Crit Care Med 2009; 30:189-209.

38. Swartz MN. Bacterial meningitis: a view of the past 90 years. N Engl J Med 2004; 351:1826-8.

39. Perrocheau A, Doyle A, Bernillon P, Varon E, de La Roque F, Cohen R, et al. Estimation du nombre total de mèningites à pneumocoque de l'enfant, par la méthode capture-recapture à 3 sources, France 2001-2002. Bull Epidemiol Hebd 2006; 2-3:16-18.
40. Hsu HE, Shutt KA, Moore MR, Beall BW, Bennett NM, Craig AS, et al. Effect of pneumococcal conjugate vaccine on pneumococcal meningitis. $\mathrm{N}$ Engl J Med 2009; 360:244-56.

41. Afonso ET, Minamisava R, Bierrenbach AL, Escalante JJC, Alencar AP, Domingues CM, et al. Effect of 10-valent pneumococcal vaccine on pneumonia among children, Brazil. Emerg Infect Dis 2013; 19:589-97.

Submitted on $26 /$ Sep/2013

Final version resubmitted on 02/Aug/2014

Approved on 18/Aug/2014 